\title{
Is exposure to mercury a driving force for the carriage of antibiotic resistance genes?
}

\begin{abstract}
Correspondence
David Skurnik

dskurnik@rics.bwh.harvard.edu
\end{abstract}

Received 17 November 2009

Accepted 19 March 2010

\author{
David Skurnik, ${ }^{1,2}$ Raymond Ruimy, ${ }^{1}$ Derren Ready, ${ }^{3}$ Etienne Ruppe, ${ }^{1}$ \\ Claire Bernède-Bauduin, ${ }^{4}$ Felix Djossou, ${ }^{5}$ Didier Guillemot, ${ }^{3}$ \\ Gerald B. Pier $^{2}$ and Antoine Andremont ${ }^{1}$
}

\author{
${ }^{1}$ EA3964 Résistance Bactérienne in Vivo, Faculté de Médecine, Université Paris-Diderot and \\ Hôpital Bichat-Claude Bernard, CNR Résistance Bactérienne dans les Flores Commensales, \\ APHP, 75018 Paris, France \\ ${ }^{2}$ Channing Laboratory, Department of Medicine, Brigham and Women's Hospital, Harvard Medical \\ School, Boston, MA, USA \\ ${ }^{3}$ Eastman Dental Hospital, UCLH NHS Foundation Trust, 256 Gray's Inn Road, London, UK \\ ${ }^{4}$ CeRBEP, Institut Pasteur/INSERM U657, Paris, France \\ ${ }^{5}$ Equipe de Recherche EA 3593, Centre Hospitalier de Cayenne, BP 6006, F-97306 Cayenne, \\ French Guyana
}

\begin{abstract}
The mercury resistance gene merA has often been found together with antibiotic resistance genes in human commensal Escherichia coli. To study this further, we analysed mercury resistance in collections of strains from various populations with different levels of mercury exposure and various levels of antibiotic resistance. The first population lived in France and had no known mercury exposure. The second lived in French Guyana and included a group of Wayampi Amerindians with a known high exposure to mercury. Carriage rates of mercury resistance were assessed by measuring the MIC and by detecting the merA gene. Mercury-resistant $E$. coli was found significantly more frequently in the populations that had the highest carriage rates of antibiotic-resistant $E$. coli and in parallel antibiotic resistance was higher in the population living in an environment with a high exposure to mercury, suggesting a possible co-selection. Exposure to mercury might be a specific driving force for the acquisition and maintenance of mobile antibiotic resistance gene carriage in the absence of antibiotic selective pressure.
\end{abstract}

\section{INTRODUCTION}

Mercury is a heavy metal that occurs naturally in the environment in various forms (Barkay et al., 2003). Methylmercury, one of the most potent neurotoxins known, has adverse effects on the health of animals and humans (Magos \& Clarkson, 2006). The consumption of fresh, contaminated fish is the most common means by which humans are exposed to mercury (Barkay et al., 2003). Human activity releases mercury into the air, water and soil (Barkay et al., 2003). The prevalence of mercuryresistant bacteria has been shown to increase in mercurypolluted environments (Barkay \& Olson, 1986; Rasmussen \& Sorensen, 1998) mainly through selection for acquisition of resistance.

The principal mechanism of bacterial resistance to mercury is the reduction of the reactive ionic form of mercury $\left(\mathrm{Hg}^{2+}\right)$ to the less-reactive, volatile, elemental form $\left(\mathrm{Hg}^{0}\right)$ (Barkay et al., 2003). This reaction is catalysed by the cytosolic flavoenzyme mercuric reductase (MerA) (Fox \&
Walsh, 1982). Briefly, the mer locus consists of genes encoding synthesis of MerA and a transport system which brings $\mathrm{Hg}^{2+}$ into the cytoplasm for reduction by MerA. The genes for the entire system are arranged as an operon (the mer operon) under both positive and negative genetic regulatory control (Lee et al., 1993), and are often part of the Tn21-like transposons, which themselves can carry class 1 integrons, that cannot mobilize without the help of a transposon or an ISCR element, with one or more antibiotic resistance genes (Liebert et al., 1999). It is not clear whether the genetic linkage between antibiotic and mercury resistance is based on selection by an antibiotic pressure, by a mercury pressure, by a combined pressure or due to some other mechanism. Nonetheless, regardless of the presence of dental amalgam fillings that contain mercury, resistance to mercury is widely distributed among bacteria isolated from healthy adults and children, with the presence of mercury resistance genes almost always associated with the concomitant presence of antibiotic resistance genes (Edlund et al., 1996; Liebert et al., 1997; 
Pike et al., 2002, 2003; Ready et al., 2003, 2007; Summers et al., 1993; Wireman et al., 1997). This association between antibiotic resistance and heavy metal resistance has also been described in Staphylococcus aureus. Indeed, the S. aureus blaZ, which encodes penicillin resistance, is part of a transposable element located on a large plasmid, often with additional antimicrobial resistance genes (e.g. gentamicin and erythromycin) (Lowy, 2003). The blaZ gene was integrated into a heavy metal resistance plasmid common in the environment and associated, for example, with cadmium resistance (Massidda et al., 2006). Without these plasmid backbones, it is likely that blaZ could not have spread among isolates. Whilst heavy metal exposure did not select for penicillin resistance, it is possible that it selected for the resistances available on the plasmid backbones.

\section{METHODS}

Bacterial isolates. The isolates studied were commensal E. coli obtained from various human populations and stored in our laboratory.

Methods used to isolate and characterize the E. coli isolates have been previously reported (Grenet et al., 2004; Skurnik et al., 2008). Briefly, five lactose-positive colonies were randomly selected after culture of faecal samples on Drigalski agar without antibiotics and E. coli was identified using API 20E strips (bioMérieux). Methods for determining the antibiotic susceptibility, integron prevalence and phylogenetic groupings of the strains have previously been reported (AubryDamon et al., 2004; Grenet et al., 2004; Skurnik et al., 2005, 2008), and were used in the present study. Isolates from the same subjects with identical antibiotic-susceptibility patterns and phylogenetic groups were excluded as replicates (data not shown).

Human subjects. None of the source subjects had taken antibiotics for at least 2 months nor had they been hospitalized for the prior year.
They included two distinct populations living in different environments, each composed of two groups, one with a known higher prevalence of antibiotic resistance than the other (Table 1).

The first population was made up of subjects living in mainland France, in a region where environmental mercury exposure was low $\left(2.46 \mu \mathrm{g} \mathrm{g}^{-1}\right)$ in a study previously presented by the French government (Miquel, 2001). Within this population was a group of 77 pig farmers with high rates of carriage of antibiotic-resistant E. coli (280 strains being studied) with no contact known with a farm product that could be a source of mercury exposure, and a second group of 77 bank insurance workers matched with the farmers by age, sex and county of residence, who have been shown to less frequently carry antibiotic-resistant E. coli (286 strains being studied) (Table 1) (Aubry-Damon et al., 2004; Skurnik et al., 2005).

The second population was made up of subjects living in French Guyana. Within this population was a group of 56 Wayampi Amerindians living in isolated areas of south Guyana, previously shown to carry high rates of antibiotic-resistant E. coli (161 strains being studied) (Skurnik et al., 2008), and who have also been heavily exposed to mercury, probably due to gold mining activities (AFSSETInVS, 2004; BASAG, 2007). About $15 \%$ of the Wayampi children had a level of mercury in their hair that was higher than the $10 \mu \mathrm{g} \mathrm{g}^{-1}$ recommended by the World Health Organization, and the level of mercury among all of the Wayampi population $\left(7.2 \mu \mathrm{g} \mathrm{g}^{-1}\right)$ was the highest among individuals tested in French Guyana in 2004 (BASAG, 2007). Of note, all dental care in the Wayampi is administered by intermittent visits of odontologists from the capital city who do not use mercury-containing dental restorations in that population.

The other group was composed of age- and sex-matched French expatriates living in Cayenne City, the capital of French Guyana, located on the northern coast of the territory where the mercury exposure is not significant and who carry lower rates of antibioticresistant E. coli (122 strains studied) (Table 1) (AFSSET-InVS, 2004; BASAG, 2007; Skurnik et al., 2008).

Mercury resistance. MICs of mercury were determined for each $E$. coli isolate included in the study. Duplicate determinations were made

Table 1. Main characteristics of the studied populations

\begin{tabular}{|c|c|c|}
\hline Characteristic & Result & Comment/reference \\
\hline \multicolumn{3}{|l|}{ Population 1 (France) } \\
\hline Antibiotic exposure & Pig farmer $>$ bank insurance workers & $\begin{array}{l}\text { Exposure through antibiotic therapy (Aubry- } \\
\text { Damon et al., 2004) }\end{array}$ \\
\hline Mercury exposure & Pig farmer $=$ bank insurance workers & No difference (Miquel, 2001) \\
\hline Prevalence of antibiotic resistance & Pig farmer $>$ bank insurance workers & $\begin{array}{l}\text { Exposure through antibiotic therapy (Aubry- } \\
\text { Damon et al., 2004) }\end{array}$ \\
\hline Prevalence of mercury resistance & Pig farmer $>$ bank insurance workers & This work \\
\hline Correlation antibiotic/mercury resistance & $\begin{array}{l}\text { Pig farmers and bank insurance workers } \\
\text { statistically significant for almost all the } \\
\text { tested markers }\end{array}$ & $\begin{array}{l}\text { Exposure through antibiotic therapy (Aubry- } \\
\text { Damon et al., 2004) }\end{array}$ \\
\hline \multicolumn{3}{|l|}{ Population 2 (French Guyana) } \\
\hline Antibiotic exposure & Wayampi $<$ expatriates & Grenet et al. (2004) \\
\hline Mercury exposure & Wayampi $>$ expatriates & AFSSET-InVS (2004), BASAG (2007) \\
\hline Prevalence of antibiotic resistance & Wayampi $>$ expatriates & Grenet et al. (2004) \\
\hline Prevalence of mercury resistance & Wayampi $>$ expatriates & This work \\
\hline Correlation antibiotic/mercury resistance & $\begin{array}{l}\text { Wayampi statistically significant only for } \\
\text { streptomycin and for trimethoprim; } \\
\text { expatriates statistically significant for almost } \\
\text { all the tested markers }\end{array}$ & $\begin{array}{l}\text { Exposure through antibiotic therapy (Aubry- } \\
\text { Damon et al., 2004) }\end{array}$ \\
\hline
\end{tabular}


by the agar dilution method, as described by Ready et al. (2003). In brief, cultures were prepared from stock collections stored at $-80{ }^{\circ} \mathrm{C}$. Mercuric chloride was added to Müller-Hinton agar at concentrations ranging from 0.125 to $512 \mu \mathrm{M}$. Mercury-resistant (NCTC 50581) and mercury-susceptible (8325-4) control strains of $S$. aureus were included in every batch of susceptibility tests as suggested by Ready et al. (2003). The mercury-resistant strain Enterococcus faecium NCTC $6641 \mathrm{H} 1$ and the mercury-sensitive E. coli strain NCTC 10418 were used as additional controls. The four controls were included in duplicate in all of the tests. The positive controls had an MIC of $512 \mu \mathrm{M}$. The negative controls had an MIC of $16 \mu \mathrm{M}$.

The presence of the merA gene was detected in the strains by real-time PCR, using degenerate primers A1s.F (5'-TCCGCAAGTNGCVACBGTNGG-3') and A5-n.r (5'-ACCATCGTCAGRTARGGRAAVA$\left.3^{\prime}\right)$ as described by Vetriani et al. (2005). Amplification was in an ABI Prism 7000 SDS thermocycler (Applera) under the following conditions: $95{ }^{\circ} \mathrm{C}$ for $10 \mathrm{~min}$ followed by 30 cycles of $95{ }^{\circ} \mathrm{C}$ for $15 \mathrm{~s}$ and $60{ }^{\circ} \mathrm{C}$ for $1 \mathrm{~min}$.

Statistical analysis. The chi-square test was used for between-group comparisons, and Fisher's exact test was used when the expected frequencies were under 5 . The MacNemar test was used for betweengroup comparisons of matched observations. A $P$-value of $<0.05$ was considered significant. Statistical analyses were performed with Stata software, version 8.0.

\section{RESULTS AND DISCUSSION}

A total of 849 E. coli strains were tested in duplicate. We found 713 strains with an MIC to mercury of $<32 \mu \mathrm{M}$ and 136 strains with an MIC $>64 \mu \mathrm{M}$ that were regarded as mercury-resistant (Pike et al., 2002). The presence of the merA gene was detected in all of the resistant strains and in none of the sensitive ones. These 849 commensal E. coli tested came from a total of 266 subjects. Among these subjects, $72(27 \%)$ were considered carriers of mercuryresistant E. coli due to the identification of at least one isolate of mercury-resistant E. coli.

The prevalence of carriers of mercury-resistant E. coli was significantly higher in the French mainland pig farmers ( $36.4 \%, 28$ of 77 subjects carrying 69 resistant strains) than in the French insurance workers $(19.5 \%, 15$ of 77 subjects carrying 30 resistant strains) $(P=0.02)$, and significantly higher in the Wayampi $(35.7 \%, 20$ subjects carrying 21 resistant strains) than in the French expatriates (16.1\%, 9 subjects carrying 16 resistant strains) $(P=0.03)$. Thus, in both the French and the Guyanese populations, carriage rates of mercury-resistant commensal E. coli were significantly higher in the groups were there was an overall higher prevalence of antibiotic resistance. This confirmed the wellestablished link between mercury and antibiotic resistance (Edlund et al., 1996; Liebert et al., 1997; Pike et al., 2002, 2003; Ready et al., 2003, 2007; Summers et al., 1993; Wireman et al., 1997).

The Wayampi have been heavily exposed to mercury (AFSSET-InVS, 2004; BASAG, 2007) and the Tn21-like transposons, which often contain the merA gene (Liebert et al., 1999), can by chance mobilize an antibiotic containing a class 1 integron onto a plasmid. Thus a putative overall sequence of events for the Wayampi population could be that their mercury exposure has selected merA strains and, as these strains were significantly associated with class 1 integrons carrying aad and dhfr cassettes (Skurnik et al., 2008 ) when compared to merA negative strains (6/16 versus $15 / 145, P=0.005)$, this mercury exposure could also have selected streptomycin and trimethoprim resistances.

This hypothesis would explain, in part, why we previously found that antibiotic-resistant E. coli was frequently isolated from the Wayampi although their antibiotic use is limited in comparison to residents of mainland France (Grenet et al., 2004). Indeed, the poor hygienic living conditions of the Wayampi may lead to cross-transmission of resistant strains, but our results suggest that this might be only part of the explanation, as environmental exposure to mercury might also play a significant role in selecting out for merA-linked antibiotic-resistant genes present within class I integrons. Other authors were recently confronted with similar findings of unexpectedly high levels of acquired antibiotic resistance in commensal E. coli isolates from a remote Guaraní Indian community in Bolivia (Pallecchi et al., 2007), combined with very low levels of antibiotic exposure and little contact with the outside world. They suggested that in the absence of direct antibiotic exposure, the maintenance of such a high prevalence of antibiotic resistance might be a selective advantage conferred by genetic determinants linking antibiotic resistance with resistance genes for heavy metal, which in turn might facilitate survival in the environment. It is also possible that mercury resistance plasmids are of a particular type which is more successful than others and thus they could confer a fitness advantage even in the absence of any selective pressure.

Overall, although our study was retrospective and lacked a direct measurement of mercury exposure in the subjects studied, the data that we have presented support the hypothesized link between mercury and antibiotic resistance, which likely should be studied prospectively on a larger scale.

\section{ACKNOWLEDGEMENTS}

This work was supported by the French National Reference Center for Antibiotic Resistance, by the ERAES project [ANR (contract \#05/ 9114) and AFSSET (contract \#23.CF25S2B and EST-09-21)]. Some of this work was undertaken at UCLH/UCL, which received a proportion of funding from the Department of Health's NIHR Biomedical Research Centres Funding Scheme, UK.

\section{REFERENCES}

AFSSET-InVS (2004). Journée scientifique "Mercure Guyane". http://www.afsset.fr/index.php?pageid=738\&parentid=424/

Aubry-Damon, H., Grenet, K., Sall-Ndiaye, P., Che, D., Cordeiro, E., Bougnoux, M. E., Rigaud, E., Le Strat, Y., Lemanissier, V. \& other authors (2004). Antimicrobial resistance in commensal flora of pig farmers. Emerg Infect Dis 10, 873-879. 
Barkay, T. \& Olson, B. H. (1986). Phenotypic and genotypic adaptation of aerobic heterotrophic sediment bacterial communities to mercury stress. Appl Environ Microbiol 52, 403-406.

Barkay, T., Miller, S. M. \& Summers, A. O. (2003). Bacterial mercury resistance from atoms to ecosystems. FEMS Microbiol Rev 27, 355-384.

BASAG (2007). Le mercure en Guyane. Bulletin d'Alerte et de Surveillance Antilles Guyane. http://www.invs.sante.fr/publications/ basag/Basag2007-7.pdf/

Edlund, C., Bjorkman, L., Ekstrand, J., Sandborgh-Englund, G. \& Nord, C. E. (1996). Resistance of the normal human microflora to mercury and antimicrobials after exposure to mercury from dental amalgam fillings. Clin Infect Dis 22, 944-950.

Fox, B. \& Walsh, C. T. (1982). Mercuric reductase. Purification and characterization of a transposon-encoded flavoprotein containing an oxidation-reduction-active disulfide. J Biol Chem 257, 2498-2503.

Grenet, K., Guillemot, D., Jarlier, V., Moreau, B., Dubourdieu, S., Ruimy, R., Armand-Lefevre, L., Bau, P. \& Andremont, A. (2004). Antibacterial resistance, Wayampis Amerindians, French Guyana. Emerg Infect Dis 10, 1150-1153.

Lee, I. W., Livrelli, V., Park, S. J., Totis, P. A. \& Summers, A. O. (1993). In vivo DNA-protein interactions at the divergent mercury resistance (mer) promoters. II. Repressor/activator (MerR)-RNA polymerase interaction with merOP mutants. J Biol Chem 268, 2632-2639.

Liebert, C. A., Wireman, J., Smith, T. \& Summers, A. O. (1997). Phylogeny of mercury resistance (mer) operons of gram-negative bacteria isolated from the fecal flora of primates. Appl Environ Microbiol 63, 1066-1076.

Liebert, C. A., Hall, R. M. \& Summers, A. O. (1999). Transposon $\operatorname{Tn} 21$, flagship of the floating genome. Microbiol Mol Biol Rev 63, 507-522.

Lowy, F. D. (2003). Antimicrobial resistance: the example of Staphylococcus aureus. J Clin Invest 111, 1265-1273.

Magos, L. \& Clarkson, T. W. (2006). Overview of the clinical toxicity of mercury. Ann Clin Biochem 43, 257-268.

Massidda, O., Mingoia, M., Fadda, D., Whalen, M. B., Montanari, M. P. $\&$ Varaldo, P. E. (2006). Analysis of the $\beta$-lactamase plasmid of borderline methicillin-susceptible Staphylococcus aureus: focus on bla complex genes and cadmium resistance determinants cadD and cadX. Plasmid 55, 114-127.

Miquel, G. (2001). Effets des métaux lourds sur l'environnement et la santé. Office parlementaire d'évaluation des choix scientifiques et technologiques. Rapport 261. http://www.senat.fr/rap/l00-261/100261_mono.html

Pallecchi, L., Lucchetti, C., Bartoloni, A., Bartalesi, F., Mantella, A., Gamboa, H., Carattoli, A., Paradisi, F. \& Rossolini, G. M. (2007).
Population structure and resistance genes in antibiotic-resistant bacteria from a remote community with minimal antibiotic exposure. Antimicrob Agents Chemother 51, 1179-1184.

Pike, R., Lucas, V., Stapleton, P., Gilthorpe, M. S., Roberts, G., Rowbury, R., Richards, H., Mullany, P. \& Wilson, M. (2002). Prevalence and antibiotic resistance profile of mercury-resistant oral bacteria from children with and without mercury amalgam fillings. J Antimicrob Chemother 49, 777-783.

Pike, R., Lucas, V., Petrie, A., Roberts, G., Stapleton, P., Rowbury, R., Richards, H., Mullany, P. \& Wilson, M. (2003). Effect of restoration of children's teeth with mercury amalgam on the prevalence of mercury- and antibiotic-resistant oral bacteria. Microb Drug Resist 9, 93-97.

Rasmussen, L. D. \& Sorensen, S. J. (1998). The effect of longterm exposure to mercury on the bacterial community in marine sediment. Curr Microbiol 36, 291-297.

Ready, D., Qureshi, F., Bedi, R., Mullany, P. \& Wilson, M. (2003). Oral bacteria resistant to mercury and to antibiotics are present in children with no previous exposure to amalgam restorative materials. FEMS Microbiol Lett 223, 107-111.

Ready, D., Pratten, J., Mordan, N., Watts, E. \& Wilson, M. (2007). The effect of amalgam exposure on mercury- and antibiotic-resistant bacteria. Int J Antimicrob Agents 30, 34-39.

Skurnik, D., Le Menac'h, A., Zurakowski, D., Mazel, D., Courvalin, P., Denamur, E., Andremont, A. \& Ruimy, R. (2005). Integron-associated antibiotic resistance and phylogenetic grouping of Escherichia coli isolates from healthy subjects free of recent antibiotic exposure. Antimicrob Agents Chemother 49, 3062-3065.

Skurnik, D., Bonnet, D., Bernède-Bauduin, C., Michel, R., Guette, C., Becker, J. M., Balaire, C., Chau, F., Mohler, J. \& other authors (2008). Characteristics of human intestinal Escherichia coli with changing environments. Environ Microbiol 10, 2132-2137.

Summers, A. O., Wireman, J., Vimy, M. J., Lorscheider, F. L., Marshall, B., Levy, S. B., Bennett, S. \& Billard, L. N. (1993). Mercury released from dental "silver" fillings provokes an increase in mercury- and antibiotic-resistant bacteria in oral and intestinal floras of primates. Antimicrob Agents Chemother 37, 825-834.

Vetriani, C., Chew, Y. S., Miller, S. M., Yagi, J., Coombs, J., Lutz, R. A. \& Barkay, T. (2005). Mercury adaptation among bacteria from a deepsea hydrothermal vent. Appl Environ Microbiol 71, 220-226.

Wireman, J., Liebert, C. A., Smith, T. \& Summers, A. O. (1997). Association of mercury resistance with antibiotic resistance in the gram-negative fecal bacteria of primates. Appl Environ Microbiol 63, 4494-4503. 